\title{
Groundwater-table and recharge changes in the Piedmont region of Taihang Mountain in Gaocheng City and its relation to agricultural water use
}

\author{
Yonghui Yang ${ }^{1 *, 2}$, Masataka Watanabe ${ }^{1}$, Yasuo Sakura ${ }^{3}$, Tang Changyuan ${ }^{3}$ and Seiji Hayashi ${ }^{1}$ \\ ${ }^{1}$ Division of Soil and Water, National Institute of Environmental Studies, 16-2 Onogawa, Tsukuba, 305-8506, Japan \\ 2 Shijiazhuang Institute of Agricultural Modernization, Chinese Academy of Sciences, Shijiazhuang, 050021, China \\ ${ }^{3}$ Department of Earth Sciences, Chiba University, 1-33 Yayoi-cho, Inage-ku, Chiba 263-8522, Japan
}

\begin{abstract}
Rapid groundwater drawdown in Gaocheng City, the alluvial plain of the Taihang Mountain in the North China Plain, has become the biggest threat to agricultural sustainability. In order to determine the factors resulting in the groundwater decline and to develop a practical plan for long-term groundwater use, water-table fluctuation data were collected over a period of 25 years. The analysis showed that although the drawdown of the water-table was mainly due to water used for winter wheat production and other crops, another reason for groundwater level decline was the tremendous decline of upstream groundwater recharge. It was estimated that, compared to the 1970s, decrease in upstream groundwater recharge in the 1990s resulted in about $1.2 \mathrm{~m} / \mathrm{a}$ of groundwater level decline. Thus, decline of upstream groundwater recharge rather than agricultural water use was the main reason for the recent groundwater drawdown. On the other hand, gradually improved agricultural practices have saved a great deal of water since the 1970s. The analysis also revealed that, although the groundwater level declined during the wheat-growing season, corn-growing season and over the whole year strongly correlated with the amount of precipitation in that period, aside from one year of extremely high precipitation, precipitation did not recharge groundwater directly but affected groundwater levels through a decrease in irrigation water use. Finally, in order to maintain the groundwater balance, agricultural practices have to save about $180 \mathrm{~mm} / \mathrm{a}$ of irrigation water from their present level.
\end{abstract}

\section{Introduction}

The North China Plain (NCP) is one of the most important agricultural regions in China. Each year, it produces more than $20 \%$ of China's grain (China's Agricultural Statistics Edition Committee, 1999; Huang, 1989). Water shortage is a serious problem, threatening the long-term agricultural and industrial development and even the long-term food supply of the whole of China (Liu and He, 1996, Lester and Halweil, 1998). In Haihe Plain, the northern part of the NCP, where some big cities such as Beijing, Tianjin, and Shijiazhuang are located, water/cap a is only about $359 \mathrm{~m}^{3}$ (calculated from the data of Liu and He, 1996), which is far lower than $1000 \mathrm{~m}^{3} / \mathrm{cap} \cdot \mathrm{a}$, a benchmark of water scarcity recognised by world organisations and also in China (e.g. IPCC, 1996; National Sustainable Development Research Group of the Chinese Academy of Sciences, 2000). Rapid groundwater-table decline caused by overpumping of groundwater for irrigation is taking place in more than $40000 \mathrm{~km}^{2}$ (Chen, 1999; Hebei Department of Water Conservancy, 1998; National Bureau of Environmental Protection, 2000), which is estimated to be the largest ground water drawdown area in the world (Chen et al., 2000). In addition, in the face of rapid population and economic growth (National State Department, 1996; National Planning Committee, 1998) to 2050, a dramatic rise in water use is expected (Liu, 2000).

\footnotetext{
* To whom all correspondence should be addressed.

표-81-298-50-2599; fax: +81-298-50-2576;

e-mail: yonghui.yang@nies.go.jp

Received 20 June 2001; accepted in revised form 11 December 2001.
}

The studied region, Gaocheng County (114'38'45" $114^{\circ} 58^{\prime} 47^{\prime \prime} \mathrm{E}$ and $\left.37^{\circ} 51^{\prime} 00^{\prime \prime}-38^{\circ} 18^{\prime} 44^{\prime \prime} \mathrm{N}\right)$, falls inside this area (Fig. 1) and is located in the piedmont plain of the Taihang Mountain, which serves as the source of groundwater recharge. During the past 50 years, several different scale groundwater surveys have been carried out. Although most of these surveys were not sufficiently accurate, new water use plans were drawn up. In the 1960 s and 1970 s, most of these surveys led to optimistic plans to encourage further development of irrigation systems. After 1972, irrigation systems in the NCP were developed very quickly (Liu and Wei, 1989). By the early 1980s, small-sized cones of depression had started to form in $5 \%$ of the area while in vast areas of the central and eastern plains, groundwater depth was considered to be about equilibratory (Zhu, 1983). By the end of the 1980s, the continuous decline of the water-table, caused by the overpumping of groundwater for agriculture production, clearly suggested that agricultural practices were using too much water. Thus, agricultural water-saving technologies were gradually developed (Wang et al., 1993). However, not only did the trend in the water-table decline not change, but also the situation worsened. Sustainable development of agriculture in this region is facing huge challenges (Hebei Department of Water Conservancy, 1999).

Therefore, the objective of this study was to clarify the factors influencing fluctuation in the water-table in order to set up a more practical plan to maintain the balance of groundwater and to achieve sustainable development of agriculture in this region. Moreover, since most agricultural scientists prefer to use $\mathrm{mm}$ as the unit of irrigation in the agricultural field, rather than $\mathrm{m}^{3} / \mathrm{a} \cdot \mathrm{km}^{2}$ for the whole region, a water-saving target in $\mathrm{mm}$ from the present water-use level is preferred. 


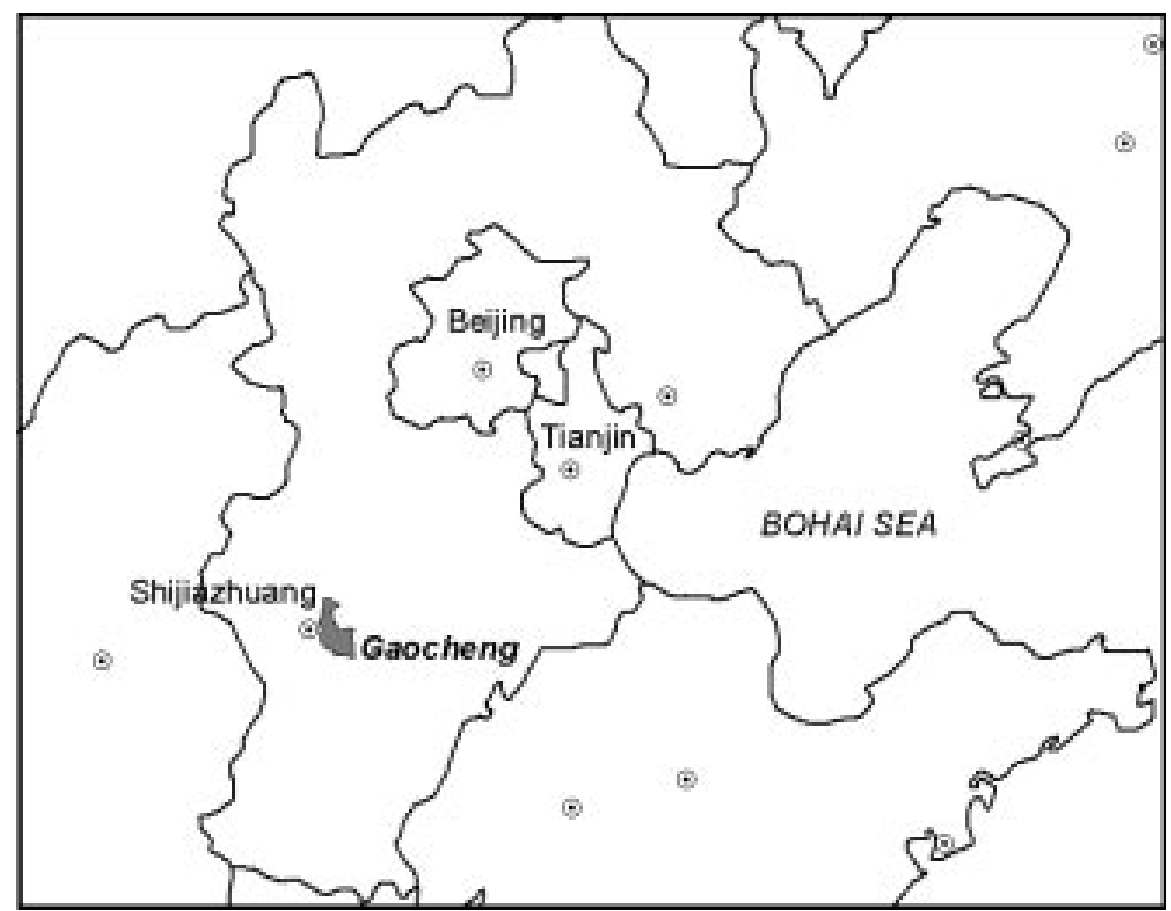

Figure 1

Location of Gaocheng City in North China

\section{Description of the hydrogeology}

The study area, Gaocheng County, covers an area of about $830 \mathrm{~km}^{2}$. Geologically, it belongs to the piedmont alluvial plain of the Taihang Mountain. The studied aquifer is the unconfined aquifer within $50 \mathrm{~m}$ of the surface, which was originally formed during the Quaternary period (Liu and Wei, 1989). The constituents of the studied aquifer are large grain and sand, and the aquifer is basically homogeneous (Zhang et al, 2000). In this county, all irrigation water is pumped from the studied shallow groundwater whereas water for industrial and domestic use comes mainly from other deep aquifers. The simplicity of the studied aquifer and its direct relation to agricultural water use establish a good background for the groundwater study.

Groundwater recharge in the region is made up of direct upstream groundwater recharge and recharge from surface water such as precipitation, irrigation, and water flow in rivers and canals. Since 1980, because of the cutoff of river water flow by big reservoirs for industrial and domestic water supply for the large upstream city of Shijiazhuang, only in the flooding season of 1988 and 1996, river water flow was observed. During the dry season, although there was some artificial water transfer through Shijin Canal, because the groundwater problem in the studied region was not as serious as that downstream, the irrigation water supply to this county from the canal was cancelled at the beginning of the 1980s. It was estimated that the recharge of groundwater from Hutuo River and Shijin Canal was less than $1 \%$ of the total groundwater recharge of Gaocheng City (Gaocheng Water Conservancy Bureau, 1992). Therefore, the groundwater recharge in Gaocheng City could be treated as comprised of the lateral recharge from upstream and the vertical recharge from precipitation and irrigation.

Because groundwater buried depth was at all times more than $7 \mathrm{~m}$ and root depth of the major crops was generally distributed in soil layers of less than $2 \mathrm{~m}$ (Zhang et al., 2000), it was clear that crops could not absorb water from groundwater directly. Any kind of water absorbed could only be supplied through pumping.
Since 1974, water-table fluctuation has been observed in 22 wells at 5 dintervals. Average groundwater depths of 22 observation wells are presented in this study.

\section{Results}

\section{General trend of groundwater decline}

In order to determine the general trend in water levels, changes in the water-table over a 25 -year period and the annual dynamics of groundwater buried depth throughout the study period are plotted in Fig. 2 and Fig. 3 respectively. Monthly changes in the groundwater level on a 25-year average are presented in Fig. 4.

Figure 3 shows the changes in groundwater buried depth and the dynamics of annual precipitation since 1974. In the 1970s, groundwater was basically balanced. Since 1978, however, the water-table has been decreasing continually, with the exception of two heavy precipitation years, 1988 and 1996, the latter of which was a one-in-30-year storm. For the whole period, the groundwater level declined $14.5 \mathrm{~m}$, which was about $0.68 \mathrm{~m} / \mathrm{a}$ on average. When 1996 was not taken into account, the water-table declined on average by $0.85 \mathrm{~m} / \mathrm{a}$.

Monthly changes in the water-table on a 25 -year average are plotted in Fig. 4. These results suggested that groundwater drawdown takes place mainly from March to June. Then, as the rainy season starts in July, groundwater levels start to rise. In this region, crop rotation is practiced, and two crops such as winter wheat and corn are planted each year. The growing period of wheat is from October to the beginning of June, and that of corn is from the middle of June to the end of September. Figure 4 clearly illustrates that groundwater drawdown is caused mainly by winter wheat production. The simplest way to decrease the decline of the groundwater-table would be to reduce the area planted with winter wheat or plant other crops such as cotton. Given that more than $70 \%$ of the local farmers' food supply is currently from wheat, purchasing food from outside is still not practical, and a simple change in agricultural crop rotation would be difficult. 

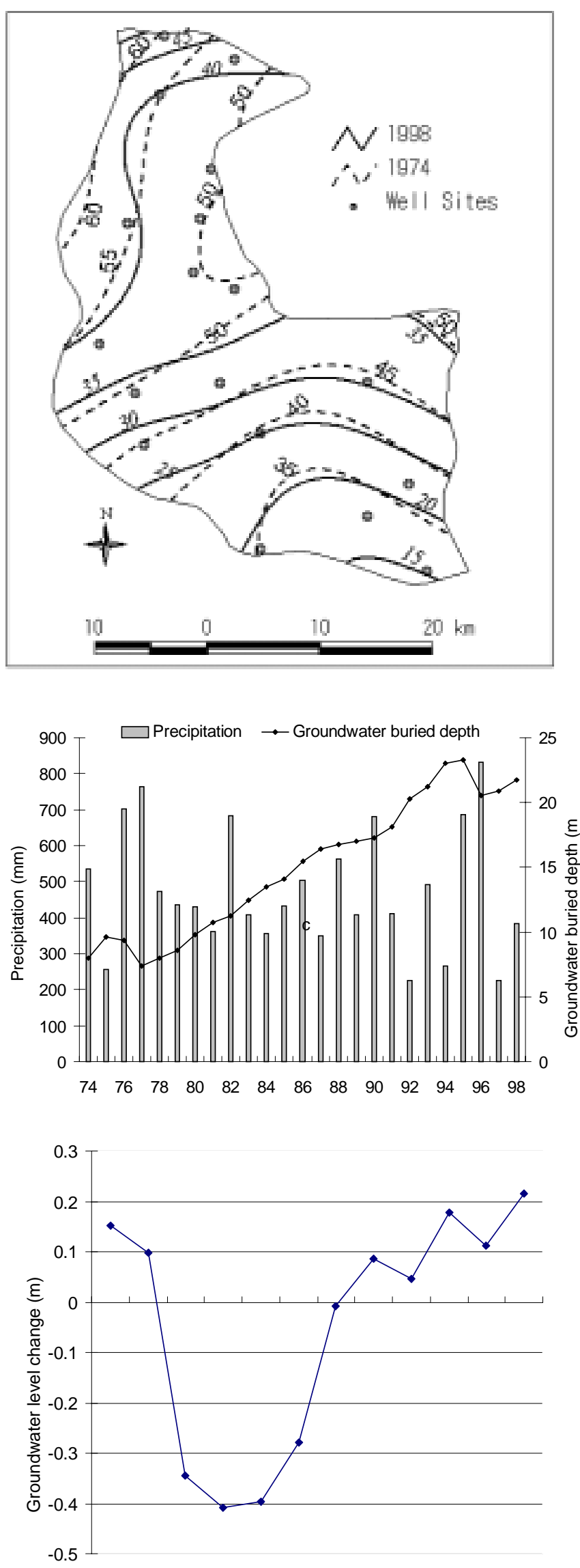

Jan Feb Mar Apr May Jun Jul Aug Sep Oct Nov Dec

\section{Groundwater level changes in different seasons and their relation to precipitation}

Since water-table changes for different crop-growing seasons differ, groundwater-table changes in different seasons were analysed separately in order to establish the main factors influencing the utilisation of groundwater.

\section{Influence of precipitation on water-table changes in wheat-growing season}

The beginning of March to the beginning of June marks the major growing season of winter wheat after its long winter dormancy. It is also the major groundwater drawdown season.

Figure 5 shows changes in the water-table and precipitation during the wheat-growing season, from March to May, since 1974. One very obvious trend indicated in Fig. 5 is the gradual slowdown of groundwater-table decline during the specified season. In the $1970 \mathrm{~s}$, groundwater showed a general decline of more than $1.5 \mathrm{~m}$, in contrast to its general decline of less than $1.0 \mathrm{~m}$ in the 1990s. Meanwhile, the relationship between water-table changes and precipitation was also found to be significant. Based on statistical analysis, the following equation was established:

$$
\mathrm{G}_{1}=7.54206-0.06945 \mathrm{~A}-0.00365 \mathrm{P} \quad \mathrm{r}=0.94
$$

where:

$\mathrm{G}_{1}$ is the change in groundwater level in meters (a negative value indicates a groundwater level rise)

$\mathrm{P}$ is the precipitation during the period in $\mathrm{mm}$

A is the last two digits of the year, between and including 74 and 98 .

Because the study aquifer is homogeneous and no substantial change in specific yield ( $\mu$ variations from 0.08 to 0.21 spatially but relatively slighter changes in depth) is taking place, changes in groundwater level basically reveal changes in groundwater utilisation by agricultural irrigation. Thus, it can be concluded that improvement in agricultural practices has already resulted in more efficient agricultural water use. The decline in the groundwater level has improved by $0.07 \mathrm{~m}$ each year, though this trend is still not sustainable over the long term. The equation also indicates that precipitation plays a very important role in easing the decline of groundwater. When precipitation increases by $100 \mathrm{~mm}$, groundwater drawdown decreases by $0.365 \mathrm{~m}$. It is believed that the effect of precipitation on groundwater level is achieved through its influence on irrigation water use rather than its direct contribution to groundwater recharge, since the amount of rainfall in every event is generally less than $20 \mathrm{~mm}$.

Figure 2 (left, top)

Comparison of water-tables at the beginning of 1974 and at the end of 1998 in Gaocheng City (19 wells were plotted; 3 wells were not observed at the beginning)

Figure 3 (left, middle)

Groundwater drawdown and precipitation changes in Gaocheng County from 1974 to 1998

Figure 4 (left, bottom)

Average monthly groundwater level changes in the 1974 to 1998 period $\left({ }^{*}\right.$ Negative data suggest a decline in the water-table, the same as in other figures) 


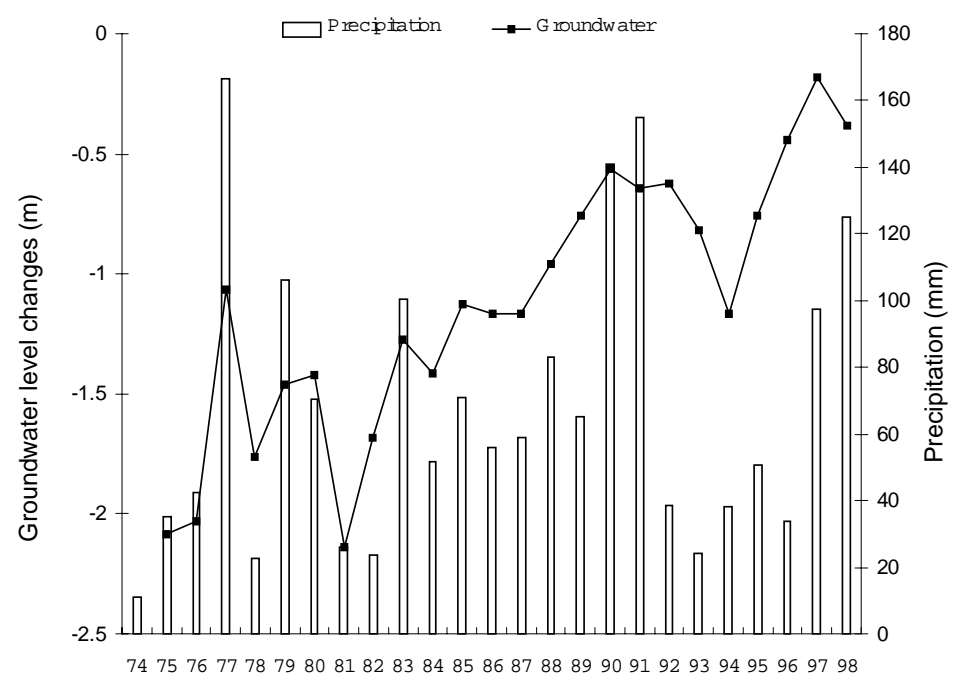

Figure 5

Groundwater level and precipitation changes in the March to May period of the wheat-growing season

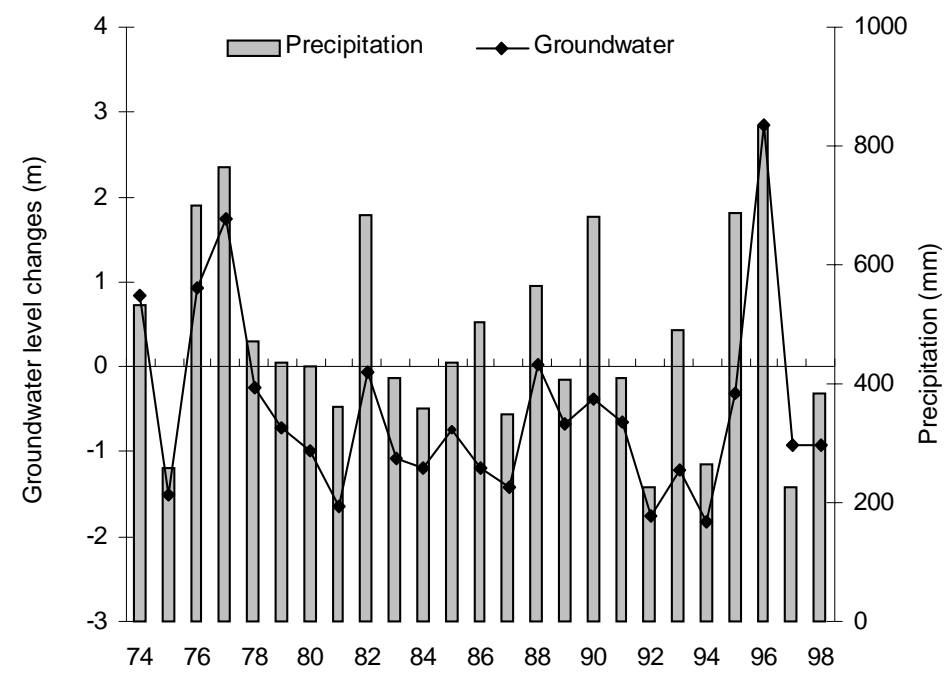

Figure 6

Groundwater level and precipitation changes in the corn-growing season (June- September)

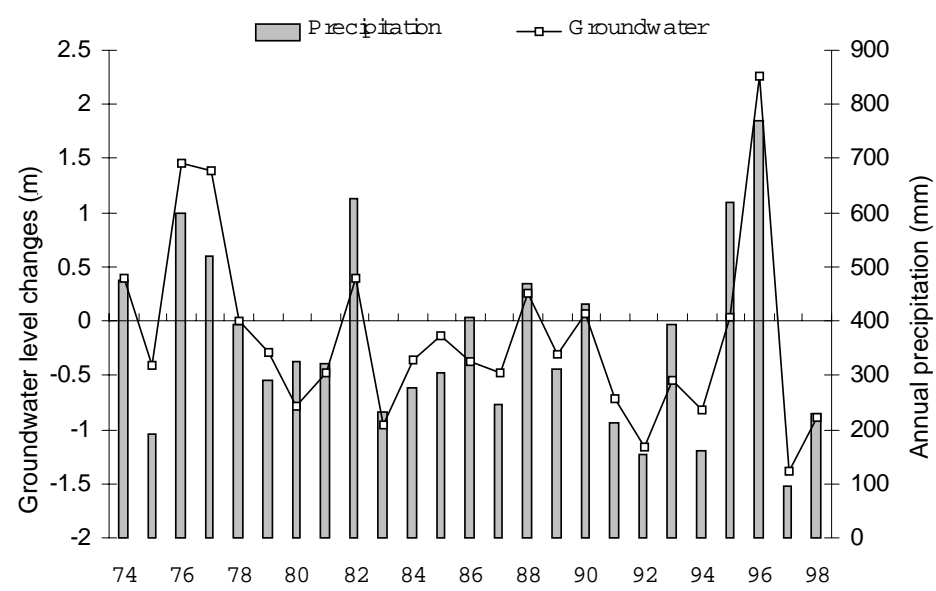

Figure 7

Similarity in the changes in the annual groundwater level and annual precipitation

\section{Influence of precipitation on water-table changes in the corn-growing season}

From the middle of June to the end of September is the growing season for corn. Since this is during the rainy season, corn production on average does not cause much groundwater drawdown. Figure 6 shows the changes in water-table levels in correspondence with annual precipitation changes since 1974 during the corn-growing season. According to the statistics, precipitation during this period (June to September) was $353 \mathrm{~mm}$ on a 25 -year average, which accounted for $76 \%$ of the annual total precipitation. The water-table still declined by $0.15 \mathrm{~m} / \mathrm{a}$ on average for this season. As indicated in Fig. 4, the only month of the groundwater decline is June, when the corn is in the seedling stage. In fact, it is very surprising that the groundwater decline in June accounted for nearly $40 \%$ of the total annual groundwater decline on a 25 -year average. In June, when the corn is still in the seedling stage, a large proportion of evapotranspiration is wasted in soil evaporation, therefore, the application of water-saving techniques would have some fundamental effect on groundwater drawdown.

The relationship between the water-table change and the periodic precipitation is described as follows:

$$
\mathrm{G}_{1}=1.73352-0.00436 \mathrm{P} \quad \mathrm{r}=0.88
$$

This relationship suggests that when precipitation during this period decreases by $100 \mathrm{~mm}$, water-table drawdown increases by $0.436 \mathrm{~m}$.

Unlike the water-table changes during the growing season of winter wheat, which is using increasingly less groundwater, the water-table changes during the corngrowing season correlated only with precipitation.

\section{Groundwater level changes and precipitation in yearly steps}

Precipitation can have an effect on groundwater level changes from two aspects: by decreasing the amount of irrigation water and by recharging groundwater directly. The basic trends of annual water-table changes and annual total precipitation changes are presented in Fig. 7. The similarity between the two curves suggests the important effect of annual precipitation on groundwater level change. Statistics also strongly suggest a significant correlation between annual precipitation and groundwater level change.

$$
\mathrm{G}_{1}=3.214-0.00558 \mathrm{P} \quad \mathrm{r}=0.84
$$

Eq. (3) indicates that when annual precipitation decreases by $100 \mathrm{~mm}$, the groundwater level drops by $0.558 \mathrm{~m}$.

\section{Groundwater recharge}

\section{Groundwater recharge in dry and low irrigation season}

Figure 4 shows that the water-table starts to rise after August. In particular, during November to February, low agricultural water use and very low precipitation (only $24 \mathrm{~mm}$ in four months on average) creates a relatively 
simple situation for the study of groundwater recharge. Since the effect of water pumping and precipitation recharge on groundwater level changes has become very low, groundwater level changes, to a great extent, reflect changes in groundwater recharge. Figure 8 shows the changes in the water-table from November to February since 1974. As indicated, a dramatic change in groundwater level recovery has occurred since 1984. Before 1984, in this period of 4 months, the water-table usually rose by more than $0.8 \mathrm{~m}$, in contrast to a rise of less than $0.4 \mathrm{~m}$ in most years after 1985 . Thus, it is possible that the recharge rate of groundwater change dropped dramatically between the 1970s and 1990s.

Usually, from August, with the coming of the rainy season, the groundwater level starts to recover. Figure 9 shows the relation between rises of groundwater level and annual precipitation from August to February. As indicated, directly or indirectly, rises in groundwater level during this period were strongly influenced by annual precipitation. By statistical analysis, the following two equations were developed:

$$
\begin{aligned}
\mathrm{G}_{1}= & 6.2658-0.0431 * \mathrm{P}+0.000087 * \mathrm{P}^{2} \\
& -0.00000006 * \mathrm{P}^{3} \\
& \mathrm{r}=0.82 \\
\mathrm{G}_{1}= & -5.218+0.0586 * \mathrm{~A}-4.72 \mathrm{E}-09 * \mathrm{P}^{3} \\
& \mathrm{r}=0.87
\end{aligned}
$$

Eq. (4) simply expresses the relationship between precipitation and groundwater level changes. Based on Eq. (4), Fig. 10 is plotted to demonstrate the trend of groundwater level recovery in relation to precipitation change. It is illustrated that when annual precipitation is less than $250 \mathrm{~mm}$, even in the recognised groundwater recovery period, groundwater level continues to decrease; namely, waterpumping is higher than groundwater recharge. When precipitation reaches the average annual precipitation, which was about $474 \mathrm{~mm}$ over 25 years, the groundwater level rises about $1 \mathrm{~m}$ on average. Then, as precipitation rises higher than average annual precipitation, groundwater levels rise more and more quickly.

Aside from the important influence of precipitation on groundwater, Eq. (5) suggests that the groundwater level increases over the August to February period are decreasing year by year at a rate of $0.059 \mathrm{~m} / \mathrm{a}$. Considering this change, the annual drawdown of groundwater, which was less than $1 \mathrm{~m}$ on average in the 1990s, was greatly influenced by the decline of groundwater recharge. This remains the major cause of groundwater drawdown whereas water for agricultural use is being used far more effectively.

\section{Comparison of the winter season groundwater recharge between a low precipitation year and a rich precipitation year in the 1970 s and 1990s}

As indicated in Eq. (4), when annual precipitation is less than $250 \mathrm{~mm}$, due to groundwater use by irrigation, groundwater level declined continuously even throughout the recognised groundwater recovery period. On the other hand, when precipitation is higher than $500 \mathrm{~mm}$, groundwater has a good opportunity to recover. It is believed that groundwater recovery is influenced by upstream groundwater recharge and recharge from local precipitation. Thus, a comparison of groundwater recharge between a rich-precipitation

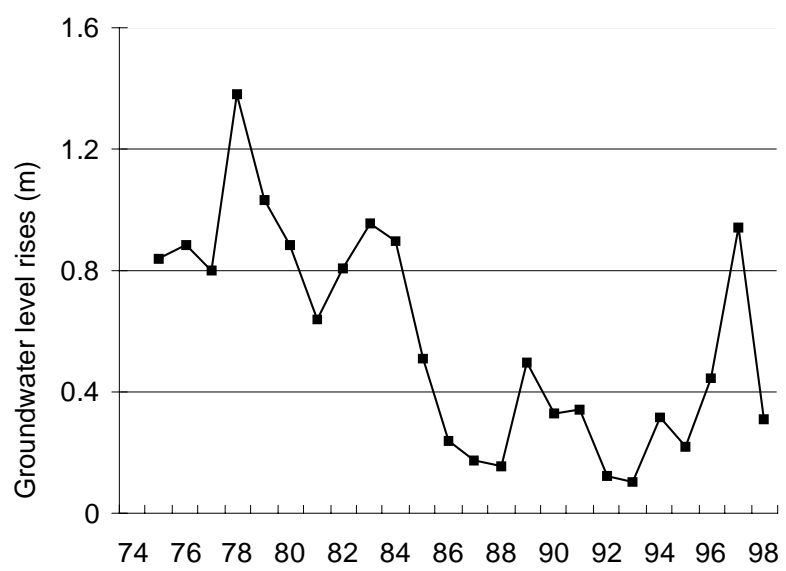

Figure 8

Water-table recovery in the November to February period

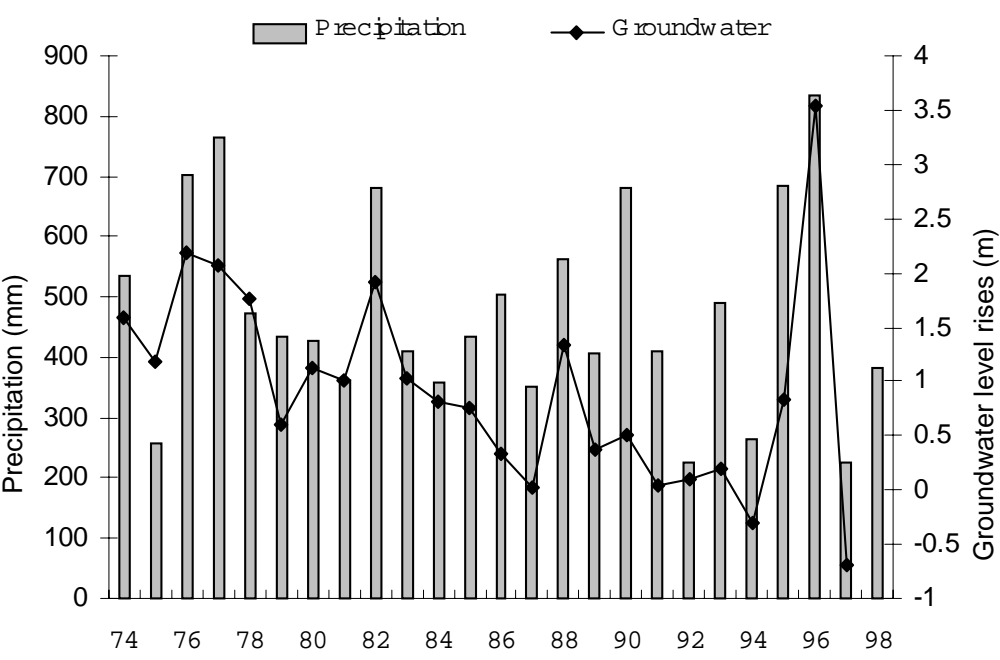

Figure 9

The groundwater level rises during August to the end of the next February and the changes in annual precipitation

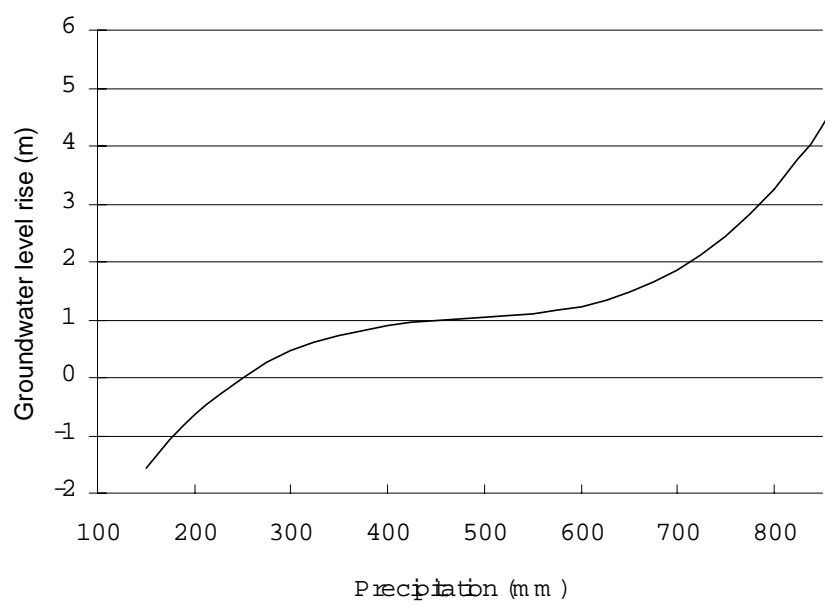

Figure 10

Predicted groundwater level rises in relation to annual precipitation 


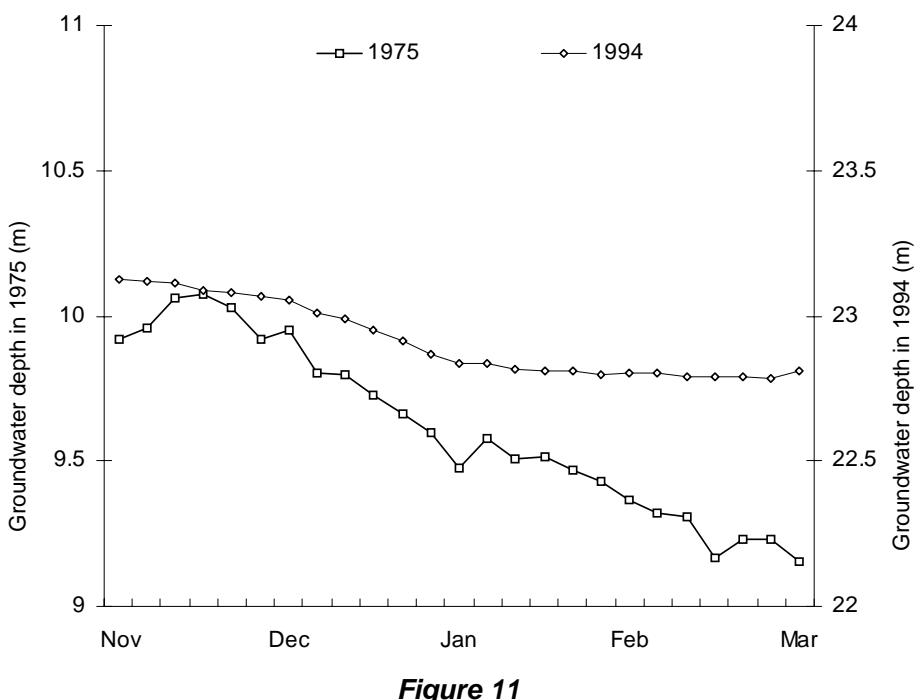

Comparison of groundwater level rises in the groundwater recovery season in 1975 and 1994, two relatively low precipitation years in the 1970s and 1990s, respectively

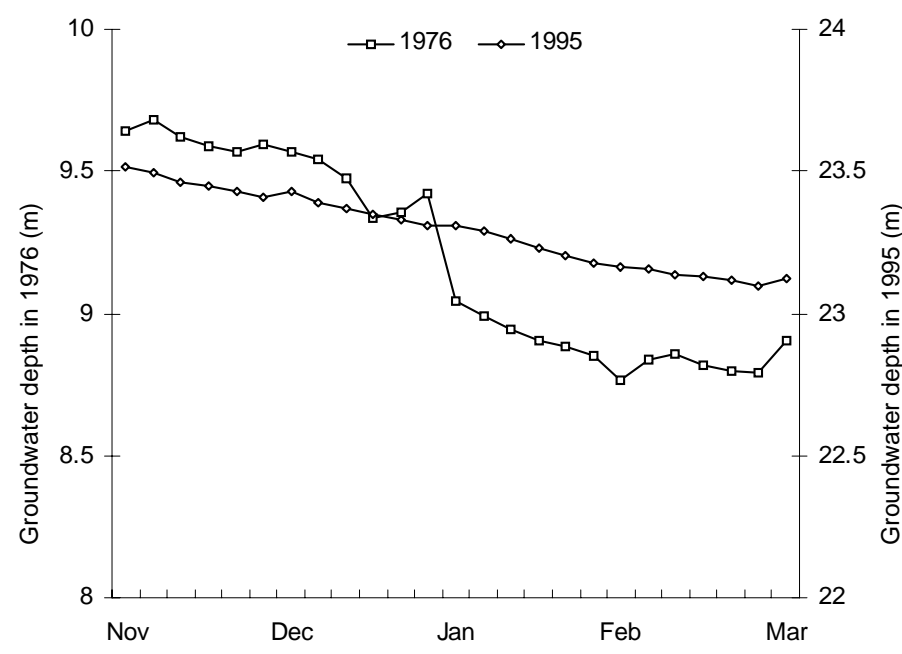

Figure 12

Comparison of groundwater level rises in the groundwater recovery season in 1976 and 1995, two relatively high precipitation years in the 1970s and 1990s, respectively

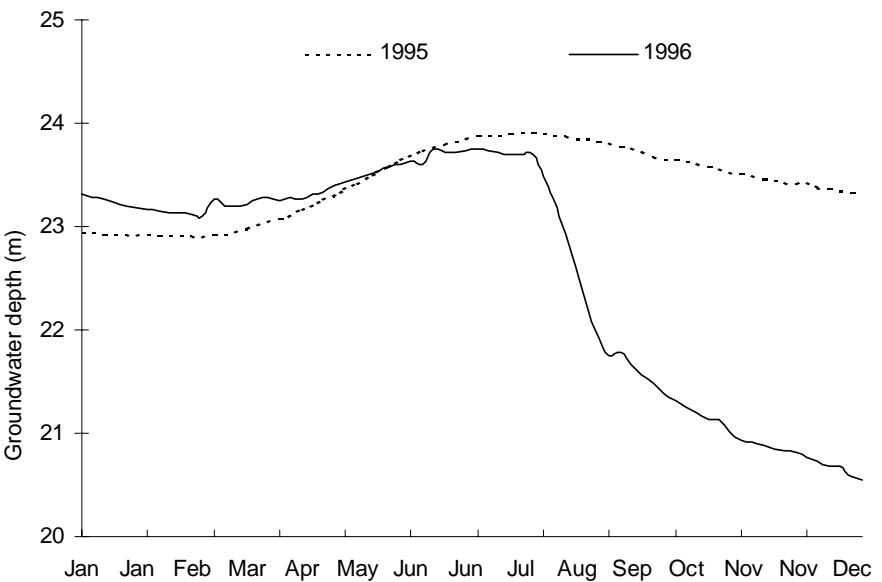

Figure 13

Comparison of groundwater level changes between 1995, a relative high precipitation year, and 1996, the highest precipitation year in 25 years year and a low-precipitation year could be helpful for identifying the changes in upstream ground water recharge and those in groundwater recharge from local precipitation.

For this purpose, 1975, with annual precipitation of $257 \mathrm{~mm}$, and 1994, with annual precipitation of $266 \mathrm{~mm}$, both precipitation rates occurring once-in-more-than-10years in accordance with 90 meteorological records in Gaocheng City, were selected to represent low-precipitation years in the 1970s and 1990s, respectively (Fig. 11). In contrast, 1976, with annual precipitation of $702 \mathrm{~mm}$, and 1995, with annual precipitation of $686 \mathrm{~mm}$, both precipitation rates occurring once-in-10-years and following the selected low-precipitation years, were selected to represent high-precipitation years in the 1970s and 1990s, respectively (Fig. 12). In addition, precipitation in 1974, the year preceding 1975, and that in 1993, the year preceding 1994, were $533 \mathrm{~mm}$ and $491 \mathrm{~mm}$, respectively, which rates were similar, and, therefore, make the comparison of groundwater recharge in the 1970s and 1990s more acceptable.

According to these two figures, in both the richprecipitation year and the low-precipitation year, because of the very low agricultural water use over the 4 months of the winter season, groundwater levels to some extent rose. Therefore, it was ascertained that groundwater recharge was still taking place in the 1990s.

However, groundwater recharge rate between the 1970s and 1990s was very different. In 1976, the rich precipitation year of the 1970s, the groundwater level rose by $0.73 \mathrm{~m}$, in contrast to a rise of only $0.34 \mathrm{~min} 1995$, the rich precipitation year in the 1990s. The difference in groundwater level rises between these two years was $0.39 \mathrm{~m}$. Similarly, in 1975 , the low-precipitation year of the 1970s, the groundwater level rose $0.76 \mathrm{~m}$, in contrast to $0.32 \mathrm{~m}$ in 1994 , the low-precipitation year of the 1990s. The difference was $0.44 \mathrm{~m}$, which is very similar to $0.39 \mathrm{~m}$, the difference in groundwater recharge between the 1970s and the 1990s in rich-precipitation years. Therefore, it is reasonable to conclude that groundwater recharge in the winter season between the 1970s and 1990s was very different.

On the other hand, in both the 1970s and the 1990s, tremendous changes in annual precipitation did not result in substantial changes in groundwater recovery. Groundwater recovery between 1975 and 1976 in the 1970s, and between 1994 and 1995 in the 1990s was very similar. Therefore, it is clear that precipitation had very little direct effect on groundwater in the winter season most years. Groundwater recharge analysis in the winter season, the results of which are shown in Fig. 5, perfectly reflect the tremendous decline of upstream groundwater recharge in the 1990s.

\section{Comparison of groundwater recharge in a high precipitation year and a very high-precipitation year}

In order to determine how strongly local precipitation can recharge to groundwater, groundwater level changes in 1996, a flooding year, taking place once-in-30-years, was selected and compared with groundwater level changes in 1995, the aforementioned high-precipitation year (Fig. 13).

As shown in Fig. 13, precipitation in 1996 was 834 
$\mathrm{mm}$, and that in 1995 was only $686 \mathrm{~mm}$. Starting from the rainy season, although both curves showed that the groundwater level was rising, the shapes of two curves were very different. As discussed above, groundwater recharge in 1995 seemed to be influenced mainly by upstream recharge in the 4 winter months. But the uniformly rising water-table of 1995 suggests that even in the rainy season, direct recharge of precipitation to groundwater is very low or nearly null. In contrast, in 1996, after a heavy rain event on August 4, sharply rising groundwater level clearly indicated the direct influence of precipitation on groundwater.

From all of the above analyses, it can be concluded that, at present, recharge of groundwater in Gaocheng City mainly results from upstream groundwater, and from precipitation-induced groundwater recharge in very high precipitation years. In most years, precipitation influenced groundwater indirectly through its direct effect on irrigation water use.

\section{Discussion and conclusion}

Given that agricultural water use accounts for more than $80 \%$ of total water use in the whole piedmont region, it appears evident that groundwater depletion is mainly caused by agricultural water use (Hebei Department Of Water Conservancy, 1998, Gaocheng Water Conservancy Bureau, 1992). Similarly, in this study, seasonal changes in the groundwater levels suggest that production of winter wheat exerts a great negative influence on the groundwater system. According to the observations of Liu et al. (1998), Liu and Wang (1999), and Xie (2001), during the growing season, winter wheat's total evapotranspiration is about $461 \mathrm{~mm}$, and precipitation over the whole growing season is usually less than $150 \mathrm{~mm}$. Thus, winter wheat's production is largely dependent on the irrigation water supply. In Fig. 4, it is shown that winter wheat is the most waterconsuming crop.

On the other hand, as discussed above, decrease in groundwater recharge is also a major factor in groundwater drawdown. From 1990 to 1998 , the average groundwater decline was about $1.1 \mathrm{~m} / \mathrm{a}$ (not including 1996, when the groundwater level rose by $2.84 \mathrm{~m}$, or the average would be $0.57 \mathrm{~m} / \mathrm{a}$ ). However, the difference in lateral or upstream groundwater recharge between the 1970s and 1990s during the 4 winter months varied between $0.39 \mathrm{~m}$ and $0.44 \mathrm{~m}$, which is about $1.2 \mathrm{~m} / \mathrm{a}$. Thus, it is reasonable to say that with a groundwater recharge rate at the level it was in the 1970s, groundwater decline should not have been a problem in 1990s. It is believed that the application of agricultural water-saving techniques has already resulted in large amounts of water savings in irrigation and agricultural production. The decrease in upstream groundwater recharge, which can be caused by over-exploitation of upstream groundwater, the impoundment of river water for domestic and industrial water use in Shijiazhuang City, the decrease in a groundwater recharge sectional area resulting from groundwater decline itself, and so on, is a very important factor affecting the present water-table decline.

Analysis also indicated the important and positive influence of precipitation on groundwater. When annual total precipitation decreases by $100 \mathrm{~mm}$, the groundwater level declines by $0.56 \mathrm{~m} / \mathrm{a}$. Similarly, when precipitation in the wheat-growing season and corn-growing season decreases by $100 \mathrm{~mm}$, the groundwater level declines $0.37 \mathrm{~m}$ and $0.44 \mathrm{~m}$, respectively. Since direct recharge of precipitation during normal precipitation years is very low or does not occur, precipitation is either evaporated by crops or stored in soil layers. In general, in the wheat-growing season, precipitationuse efficiency (PUE) was the lowest. This is possibly due to a large proportion of rainfall interception when rainfall in each event is very low. In the rainy season, heavy rainfall can improve the PUE, and a high amount of rainfall in a short period could make it possible for the soil to store some water for the coming period of wheat production. Thus, the influence of precipitation in the rainy season on groundwater is less than the influence of annual precipitation on annual groundwater changes. Therefore, the response of groundwater level to rainfall in a whole year may better reflect the relationship between irrigation water use and groundwater level change; namely, when $100 \mathrm{~mm}$ of irrigation water is saved, groundwater drawdown drops by about $0.56 \mathrm{~m}$. This has been proved to be exactly correct when the specific water yield $(\mu)$ is 0.12 (Gaocheng County Water Conservancy Bureau, 1992), and when considering that the irrigated agricultural field accounts for only $2 / 3$ of the whole Gaocheng City area (the area of groundwater layer). Thus, to achieve sustainable use of groundwater - that is, to decrease the groundwater level decline from $1.1 \mathrm{~m} / \mathrm{a}$ in the $1990 \mathrm{~s}$ (not including 1996) to zero in order to maintain the groundwater balance, about $180 \mathrm{~mm}$ of irrigation water has to be saved.

\section{Acknowledgements}

The author thanks the Japan Science and Technology Agency for support in the form of an STA fellowship. The help of Dr Wang Qinxue, Prof Zhang Xiying and Dr Zhang Zhaoji is acknowledged. I am grateful to Prof GJ van Tonder of the University of the Free State, the reviewer of my paper, for his valuable comments and detailed correction for the paper. Thanks are also given to Mrs. Hu Haizhen of the Bureau of Water Conservancy of Gaocheng City (BWCGC) and to BWCGC for the permission to use their respective data for the analysis. This work is supported by Asia-Pacific Environmental Innovation Strategy Project.

\section{References}

CHINA'S AGRICULTURAL STATISTICS EDITION COMMITTEE (1999) China's Agriculture Statistics. Chinese Agricultural Press.

CHEN W (1999) Groundwater of Hebei Province. Chinese Geological Press, China. 448-456.

CHEN F, ZHOU J and YANG S (2000) North China Plain is becoming the biggest groundwater drawdown area in the world. Chinese Xinhua News Agency. July 19.

GAOCHENG WATER CONSERVANCY BUREAU (1992) Long-term Water Use Plan for Gaocheng County.

HEBEI DEPARTMENT OF WATER CONSERVANCY (1998) Hebei Water Resources Statistics Year Book for 1997.

HEBEI DEPARTMENT OF WATER CONSERVANCY (1999) Programming Report of Hebei Groundwater Resources Utilization. 164-227.

HUANG B (1989) Agriculture and river conservancy of the North China Plains in relation to the potential productivity of the terrain. Study on Agro-Ecological Environment. 3-16.

IPCC (1996) In: Houghton JT, Meira Filho LG, Callander BA, et al. (eds.) IPCC Second Assessment Report: Climate Change 1995: The Science of Climate Change. Cambridge University Press, United Kingdom.

LESTER B and HALWEIL B (1998) China's Water Shortage Could Shake World Food Security. World Watch, July/August.

LIU C and WEI Z (1989) Hydrology and Agricultural Water Resources in North China Plain. Scientific Press, China. 61-180.

LIU C and HE X (1996) Strategies for Water Problems in the $21^{\text {st }}$ Century in China. Scientific Press, China, 1-25.

LIU C, ZHANG X and YOU M (1998) Observation of winter wheat evapotranspiration by large lysimeter and evaporation by small lysimeters. Chinese J. Hydraul. Eng. 1998 (10) 36-39.

LIU C and WANG H (1999) The Interface Processes of Water Movement in the Soil-Crop-Atmosphere System and Water-Saving Regulation. Scientific Press, China. 10-37. 
LIU C and HE X (2000) Analysis on water demand of the first half of the $21^{\text {st }}$ century in China. China Water Resour. 2000 (1) 19-20.

NATIONAL BUREAU OF ENVIRONMENTAL PROTECTION (2000) China's Environmental Situation Report in 2000, Part II: Water Environment Condition. People's Daily, June 7.

NATIONAL PLANNING COMMITTEE (1998) Report of Population, Resources and Environment of China in 1997. Edited by: Institute of Territory Development and Regional Economy. Chinese Environmental Sciences Press, Beijing, China.

NATIONAL STATE DEPARTMENT (1996) China's Food Problem White Book. People's Daily, Oct. 25.

NATIONAL SUSTAINABLE DEVELOPMENT RESEARCH GROUP OF THE CHINESE ACADEMY OF SCIENCES (2000) Strategic Report of Sustainable Development of China. Scientific Publishing House, Beijing, China. 110-261.
WANG X,ZHAOC and CHENH(1993) Study on Water-Saving Agriculture and Water-Saving Technology, Meteorological Press, China. 59-68.

XIE X (2001) A study on the water cycle in an agro-ecosystem and the relationship between crops and water. Chinese J. of Eco-Agric. 9 (1) 9-12.

ZHANG Z, OTSUBO K, ZHU Y and ISHII T (2000) Groundwater resources and related environmental deterioration in the Hebei Plain. In: Kuninori Otsubo (eds.) LU/GEC Project Research Report VI. 215226.

ZHU Y (1983) Shallow groundwater resources of the Huang-Huai-Hai plain. In: AK Biswas, D Zuo, JE Nickum and C Liu (eds.) Long Distance Water Transfer: A Chinese Case Study and International Experience. 257-270. 